Journal of English Language Teaching

UNNES

\title{
EFL college students writing anxiety of English language education at Universitas Internasional Batam
}

\author{
Theodesia Lady Pratiwi ${ }^{\bowtie}$
}

Universitas Internasional Batam, Indonesia

\begin{tabular}{l} 
Article Info \\
\hline Article History: \\
Received in 29 \\
November 2020 \\
Approved in 2 July 2021 \\
Published in 28 July \\
2021 \\
\hline Keywords: Writing \\
anxiety; EFL learners; \\
levels, types and causes
\end{tabular}

\begin{abstract}
Writing is considered to be the most difficult skill to master for EFL students. This experience was faced by English Language Education (ELE) students at Universitas Internasional Batam (UIB). Based on the observation, the results of their writings were not satisfying. This study assumed that the students might feel anxious when they were writing in English. Therefore, this study aims to examine the types and causes of writing anxiety of ELE students at UIB. This study employed explanatory design of mixed method research. The research instruments were questionnaires adopted from SLWAI and CWAI developed by Cheng (2004). To extend the deeper analysis, this study conducted interviews to the high- and low-level writing anxiety students. This study found that the most dominant levels of writing anxiety is high-anxiety $(71.43 \%)$. In terms of writing anxiety, this study found that cognitive anxiety is the most dominant type with the mean of 26.37 . Next, when studying the cause of writing anxiety, the most dominant cause was linguistic difficulties. This result was in line with the interviews with high-and low- writing anxiety students. Students with both high and low writing anxiety still found that linguistic difficulties affect their writing anxiety. Therefore, the learning process at English Language Education needs to be equipped with sufficient linguistic competences in the first year, such as vocabulary, grammar, and punctuation.
\end{abstract}

\footnotetext{
$\square$ Correspondence Address:

Jl. Gajah Mada, Sei Ladi, Tiban Indah, Sekupang,

Batam, Kepulauan Riau, Indonesia 29442
}

E-mail: theodesia@uib.ac.id 


\section{INTRODUCTION}

English as a lingua franca has generally four skills, namely listening, reading, speaking, and writing. Listening and reading skill are receptive skills, meanwhile speaking and writing is a productive skill. When it comes to productive skills, students will have to face some difficulties.

Talking specifically about writing skill, writing is considered demanding, especially for EFL (English as Foreign Language) and ESL (English as Second Language) learners (Daud et al., 2007). It is demanding since English is not their first language. When writing, they need to think first with their own language and then translate it into English. Furthermore, requirements of good appropriate grammar, punctuation, and vocabulary make it more difficult for EFL and ESL Learners. This study already observed that English Language Education students at Universitas Internasional Batam found difficulties to fulfill the requirements. The difficulties lead to students' anxiety to apply the writing skill.

Zhang (2011) claims that when students are required to perform certain activities of productive skills, they will experience anxiety. Spielberg (1983, cited in Horwitz, 2001) defines anxiety as a feeling of pressure, uneasiness, nervousness, and worry. Furthermore, MacIntyre \& Gardner (1994) define second language anxiety as "the feeling of tension and apprehension specially associated with second language contexts, including speaking, listening". In other words, related to language skills, anxiety is a feeling of pressured, worry, and uneasiness that is related to language skills.

Specifically, Takahashi (2009) states that writing anxiety does not emerge because of the students are lack of writing ability, but it is caused by a feeling of fear in the writing process. AlSawalha \& Chow (2012) also add that writing anxiety is feelings that affect someone's in the process the writing; started from the brainstorming the idea, drafting, revising, and finishing the writing; even though he/she is actually possess the skills. In other words, writing anxiety is more related to students' fear to the writing process. Writing anxiety is not caused by their lack writing competence. Specifically, writing anxiety that is experienced by students of English Language Education at Universitas Internasional Batam may affect their writing performance during the class.

Cheng (2004) categorizes writing anxiety into three types, namely somatic anxiety, cognitive anxiety, and avoidance behavior. Cognitive anxiety related to how someone thinks of other people judgments on their writing skills that affects their achievement on writing competencies. The judgments may come from teachers, partners, and colleagues. It leads them be afraid of not being able to accomplishing those judgments or expectations. Somatic anxiety is dealing with psychological aspects which are caused by their anxiety, such as the pressured and nervous feeling. The last, avoidance behavior is the anxiety that leads someone not willing to write. These anxieties may be caused by several reasons. Zhang (2011) mentions that writing anxiety may be caused by higher expectations of the teacher, fear of the tests, lack of writing competence, and etc.

Anxiety commonly happens to EFL learners. Horwitz et al. (1986) proposes a concept of foreign language anxiety which means a complex feeling, behavior, and attitude toward distinctive language learning process. This anxiety, then, leads the students to be reluctant to produce the languages.

Among the four skills of English language, writing is the most difficult skills that students need to struggle. When writing, it is necessary to find appropriate words, apply correct grammatical conventions, and link their ideas into a coherent text (Chamot, 2005). Writing anxiety is defined as feelings of someone toward their ability when dealing with writing that affect their writing ability (AlSawalha \& Chow, 2012). Further, Hassan (2001) states that writing anxiety is an anxiety that potentially happen to individuals when writing because it contains some writing requirements and evaluation. In other words, writing anxiety is someone's feeling, behavior, and attitudes toward writing because of the writing process and evaluation. Writing anxiety may lead the students to a poor performance. Horwitz et al. (1986) found that there was a relation between writing anxiety and students' performance; in other words, students who possess higher levels of anxiety may result in lower grades than students with lower levels of anxiety.

Several studies were conducted to discover the causes of writing anxiety. According to some researchers, there are some causes of writing anxiety. The first cause is fear of negative evaluation and fear of test. Zhang (2011) states that students will feel anxious if they know that their writing is being evaluated. It can be caused by teachers' high expectation and inability of the students to achieve teachers' expectation that may cause teachers' negative feedback or evaluation. The second cause is time pressure. Regarding time pressure, students may feel pressured with the allotted time during the test since writing is a productive skill (Rezaei \& Jafari, 2014). Therefore, they find that they need extra 
time to write, especially they are writing in a language that is not their mother language. Even, they need to ensure that their writing can fulfill the teachers' expectation. The third cause is low selfconfidence. When dealing with productive skill, students must have self-confidence to produce languages. Hassan (2001) adds that even students with good writing ability may affect their performance because they feel anxious and believe that they cannot write well.

Insufficient writing technique can also impact negatively to students' writing performance. Writing requires good ability and techniques, such as grammar, mechanics, diction (word choice), coherence, idea organization, and etc. These requirements may cause the students who are lack of competence may find writing anxiety (Hassan, 2001). Next, language difficulties are a common problem for EFL students when they have to compose in English. The language difficulties may make the students lazier to write since they may find some problems with lack of grammar ability and lack of vocabulary mastery (Zhang, 2011). Lastly, pressure for perfect work may affect students' writing anxiety. Teachers, sometimes, may not realize that they put high demands and expectations on students' writing. Bloom (1981) states that demand for perfect work may overwhelm and burden the students because perfect work may have higher and more difficult standard.

Based on the research, Cheng (2004) summarizes causes of writing anxiety based on some studies and then developed a questionnaire to examine causes of writing anxiety, namely Causes of Writing Anxiety Inventory (CWAI). Research results on causes of writing anxiety may vary. Rezaei \& Jafari (2014) analyzed 120 Iranian students (EFL learners), specifically students of English Department who are taking Advanced Writing Course, in two higher education institutions. They found out that students may feel anxious when writing is because they were afraid of comments from the teacher and the difficulty in language, such as word choice and grammatical features. It, then, leads them to feel unconfident when writing and being afraid of writing tests.

The study of writing anxiety was also conducted to EFL students in one of universities in East Java by Wahyuni \& Umam (2017). This study found that the most causes of writing anxiety of students are fear of teachers' negative comments, fear of writing tests, insufficient writing practice, and insufficient writing technique. In addition, Kusumaningputri et al. (2018) examined EFL learners in university in East Java as well. They discovered causes of writing anxiety. Some of them are because students do not get enough practice that affects their writing techniques. Besides, students find it is hard to write in their second or foreign language. In addition, students also feel pressured and stressed when writing tests because of the limited time allocation during the tests.

According to research results of Cheng (2004), writing anxiety is divided into three types, namely cognitive anxiety, somatic anxiety, and avoidance anxiety. First, cognitive anxiety refers to what students think or perceive about their writing competency and people judgments. It may include the expectation or demand of the teachers that causes the students feel depressed to achieve that expectation. In other words, cognitive anxiety is associated to mental states of the students when they are dealing with evaluation or external perception. Students already underestimate themselves that they are not able to write well or they are not good at writing.

Next, somatic anxiety can be referred to impacts of the anxiety that are faced by the students psychologically. When given a writing task, they may feel nervous and stressed, such as shaking hands, sweating, or rapid heart beating. It may get worse when students are doing a writing assignment during limited time allocation. Consequently, they sometimes lose the ideas to write. Last, avoidance anxiety simply means that the students avoid writing because of the anxiety. It results in avoidance of the students to attend writing class or unwillingness to write.

Based on that finding, Cheng (2004) developed a questionnaire that is commonly known as Second Language Writing Anxiety Inventory (SLWAI). This questionnaire is a 5-likert scale questionnaire that can be distributed to students to find out their writing anxiety.

Many studies already draw up the issue of writing anxiety. Masriani et al. (2018) surveyed 41 students of Universitas Negeri Padang and found out that the most type of writing anxiety of the students is cognitive anxiety. The result is in line with the result of study of Wahyuni \& Umam (2017) which revealed that the most types of anxiety is cognitive anxiety. In opposite, Fitrinada et al. (2018) observed students of English Education at Sriwijaya University. The study discovered that the most type of writing anxiety of the students is somatic anxiety. It is also similar to study of Kusumaningputri et al. (2018) which found that the most dominant type of anxiety is somatic anxiety. The different results may be caused by the divergence of the learners or different characters or treatments. The previous studies mostly used quantitative data to find the most dominant type and cause of writing 
anxiety. Therefore, this study is going to get qualitative data to explore deeper explanation by conducting an interview to students with low and high writing anxiety.

Writing is a course that is offered for English Language Education students at Universitas Internasional Batam. Writing courses are divided into some steps in each semester, namely Basic Writing (the $1^{\text {st }}$ semester), Paragraph-based Writing (the $2^{\text {nd }}$ semester), Genre-based Writing (the $3^{\text {rd }}$ semester), Creative Writing (the $4^{\text {th }}$ semester), and Critical Reading \& Writing (the $5^{\text {th }}$ semester). Learning how to write in English well may be burdensome for some students since English is not their first language. It may cause some students feel writing anxiety. Therefore, this study would like to examine the levels and types of writing anxiety as well as to explore causes of writing anxiety of English Language Education students at Universitas Internasional Batam. Most of previous studies only shows the means or percentages to present the level, types, and causes of writing anxiety. However, this study would like to analyze deeper on the causes of writing anxiety based on the level. Therefore, it is expected that this study can contribute more on the methods of teaching writing at Universitas Internasional Batam.

\section{METHODS}

This study used mixed method design to find out the results. Mixed method design research, in other words, means that this study used both quantitative and qualitative data to answer the research question. Specifically, there are some designs of mixed-method designs, namely convergent parallel design, explanatory sequential design, exploratory sequential design, embedded design, transformative design, and multiphase design (Ary et al., 2010).

This study employed explanatory sequential mixed method design is a research started with collecting the quantitative data and followed by qualitative data to clarify the quantitative results (Creswell, 2012). This study collected the quantitative data by the use of questionnaires to categorize the students' level and types of writing anxiety. This research adopted a questionnaire which was developed by Cheng (2004), namely Second Language Writing Anxiety Inventory (SLWAI) and Causes of Writing Anxiety Inventory (CWAI). The questionnaire was already tested by conducting an exploratory factor analysis which showed optimized interpretability with The Cronbach's Alpha of the Inventory was 0.89 .

Creswell (2012) states that one of the important aspects of gathering the qualitative data in explanatory sequential mixed method design is to decide the sample and questions that can follow up on the quantitative data. In addition, Ary et al. (2010) explain that sequential design may perform data analysis before to do the next phase of the study. Therefore, this study analyzed the quantitative data from questionnaires to decides the level of writing anxiety. Consequently, this study interviewed students with high, moderate, and low writing anxiety in each batch of English Language Education, Universitas Internasional Batam to grow rich understanding.

\section{Respondents}

The subject of this study was English Language Education students from batch 2017 - 2019 with total number of students was 49 students. The setting of this study was English Language Education Study Program at Universitas Internasional Batam which is located at Jl. Gajah Mada, Sei Ladi, Tiban Indah, Sekupang, Batam.

\section{Instruments}

This study collected the data using two research instruments, namely questionnaires and interviews. The questionnaires adopted Second Language Writing Anxiety Inventory (SLWAI) and Causes of Writing Anxiety Inventory (CWAI) by Cheng (2004) to find out the level, types, and causes of writing anxiety of English Language Education students of Universitas Internasional Batam. SLWAI uses a 5-likert scale questionnaire consisting of 22 questions to find out types of writing anxiety. Meanwhile, CWAI also uses 5-likert scale consisting of 10 questions to find out causes of writing anxiety. The questionnaires were already pilot-tested to a group of students from the same universities by using an exploratory factor analysis.

\section{Data collection procedures}

The questionnaires were distributed through Internet Surveys or Web-based surveys by using Google Form. Ary et al. (2010) mentioned some benefits of internet surveys, namely quick and easy data collection, less costs, reducing the amount of time and effort to collect the data, and easy access for 
the participants to fill in the questionnaire. Thus, this study selected internet survey to collect the data; especially this data was collected during the outbreak of COVID-19.

After collecting data from questionnaires, this study interviewed some students. To emphasize, this study did not interview all students who filled in the questionnaires. This study interviewed the students according to the analysis of the questionnaires. In other words, this study interviewed the students according to the level of the writing anxiety, namely high writing anxiety, moderate writing anxiety, and low writing anxiety. The purpose of the interview is to extend the analysis of results.

\section{Data analysis}

The data was analyzed using a statistical analysis. Firstly, this study calculated the levels of students' writing anxiety by summing up the score of the questionnaire of each student. If the score is above 65 , the students are categorized into high levels of writing anxiety. If the score is below 50 , the students are categorized into low levels of writing anxiety. Meanwhile, if the score is between 50 to 65 , the students are categorized into moderate levels of writing anxiety. In addition, to find out the levels of writing anxiety, this study analyzed SLWAI questionnaires.

Secondly, this study calculated the questionnaire to categorize the most dominant types of writing anxiety, namely cognitive, somatic, and avoidance behavior. In addition, to find out the most dominant type of writing anxiety, this study investigated SLWAI questionnaires with total of 22 questions. Questions number 1, 3, 7, 9, 14, 17, 20, and 21 are used to identify cognitive anxiety. Then, questions number $2,6,8,11,13,15,16$, and 19 are used to examine somatic anxiety. Last, questions number $4,5,10,12,16,18$, and 22 are used to investigate avoidance behavior. To identify the most dominant types, this study calculated the mean score.

Thirdly, to calculate the cause of writing anxiety, this study analyzed CWAI questionnaire with total of 10 questions. To calculate the most cause of writing anxiety, this study summed up total score of each question from all respondents and ranked them from the most to least dominant cause by calculating the percentage.

After the data analysis from the questionnaire, this study interviewed the students based on their level of writing anxiety and their responds to cause of writing anxiety. The aim of the interview is to elaborate deeper analysis on the results of the questionnaire to extend the description of analysis.

\section{FINDINGS AND DISCUSSION}

This study answered two research questions, namely to find out the level and type of writing anxiety and to explore the cause of writing anxiety. Therefore, this section is going to present the results of the questionnaires regarding the level, type, and cause of writing anxiety. Besides, to get deeper and more elaborative analysis, this study is also going to elaborate the results of interview.

\section{Findings}

This section is divided into 3 (three) sections, namely level of students' writing anxiety, types of students' writing anxiety, and causes of students' writing anxiety. This study employed two 5-LikertScale questionnaires by Cheng (2004), namely Second Language Writing Anxiety Inventory (SLWAI) and Cause of Language Writing Anxiety Inventory (CLWAI).

\section{Level of writing anxiety}

Firstly, this study found out the level of students' writing anxiety into low, moderate, and high anxiety. To discover that level of writing anxiety, this study employed the questionnaire of Second Language Writing Anxiety Inventory (SLWAI) which consists of 22 questions by Cheng (2004). The questionnaires were distributed to 49 English Language Education students at Universitas Internasional Batam (ELE-UIB).

To find out the levels of writing anxiety, this study summed the score of questionnaires. If the students got the score below 50, they were categorized into Low Anxiety, while if the students got the score above 65, they were categorized into High Anxiety. On the other hand, for students who got the score between 50 and 65, they were categorized into Moderate Anxiety. 
Table 1. Levels of students' writing anxiety

\begin{tabular}{ccccc}
\hline & $\begin{array}{c}\text { Number of } \\
\text { Students }\end{array}$ & $\begin{array}{c}\text { Minimum of } \\
\text { Score }\end{array}$ & $\begin{array}{c}\text { Maximum of } \\
\text { Score }\end{array}$ & Percentage (\%) \\
\hline Total & 49 & 37 & 87 & $100 \%$ \\
High Anxiety & 36 & 63 & 87 & $71.43 \%$ \\
Moderate Anxiety & 10 & 55 & 65 & $20.41 \%$ \\
Low Anxiety & 4 & 37 & 48 & $8.16 \%$ \\
\hline
\end{tabular}

Table 1 indicated that from the total of 49 students, $71.43 \%$ of English Language Education students at Universitas Internasional Batam faced high levels of writing anxiety. The students who were in the moderate levels of writing anxiety are $20.41 \%$, meanwhile the students who were in the low levels of writing anxiety is $8.16 \%$. In other words, it can be concluded that most of students of English Language Education students at Universitas Internasional Batam still experienced high levels of writing anxiety. The result of levels of writing anxiety was similar to previous studies by

\section{Types of writing anxiety}

After analyzing the levels of students' writing anxiety, this study analyzed the types of students' writing anxiety by categorizing into three categories, namely Cognitive Anxiety, Somatic Anxiety, and Avoidance Behavior. To find out the types of writing anxiety, this study still used Second Language Writing Anxiety Inventory (SLWAI) by Cheng (2004). The results of analysis are presented in Table 2 below.

Table 2. Types of Writing Anxiety

\begin{tabular}{lccc}
\hline \multicolumn{1}{c}{$\begin{array}{c}\text { Types of Writing } \\
\text { Anxiety }\end{array}$} & $\begin{array}{c}\text { Number of } \\
\text { Students }\end{array}$ & $\begin{array}{c}\text { Total } \\
\text { Score }\end{array}$ & Mean \\
\hline Cognitive & 49 & 1292 & 26.37 \\
Somatic & 49 & 1278 & 26.08 \\
Avoidance Behavior & 49 & 930 & 18.98 \\
\hline
\end{tabular}

Table 2 showed that the mean of cognitive anxiety was 26.37 , somatic anxiety was 26.08 , and avoidance behavior was 18.98 . Therefore, cognitive anxiety became the highest mean of the anxiety. Meanwhile, somatic anxiety was the second highest mean and avoidance behavior was the lowest mean. In other words, it can be interpreted that cognitive anxiety was the most dominant type of writing anxiety which was faced by English Language Education students at Universitas Internasional Batam. As Cheng (2004) mentioned that cognitive anxiety is how students perceive evaluations or judgments from teachers or partners. In other words, it can be summed up that students of English Language Education, Universitas Internasional Batam still found worriedness or fear of lecturer's judgment and evaluation when they were writing in English. However, somatic anxiety had only slightly different mean from cognitive anxiety.

\section{Causes of writing anxiety}

Besides finding the types of writing anxiety, this study also examined the causes of writing anxiety. To investigate the causes of writing anxiety, this study employed Causes of Language Writing Anxiety Inventory (CLWAI) by Cheng (2004). That questionnaire consists of 10 questions. The results of the questionnaires are presented in the following table.

Table 3. Causes of Writing Anxiety

\begin{tabular}{clcc}
\hline No. & \multicolumn{1}{c}{ Cause of Writing Anxiety } & Total & Percentage \\
\hline 1 & Linguistic difficulties & 205 & $11.63 \%$ \\
2 & Time pressure & 185 & $10.49 \%$ \\
3 & Insufficient writing technique & 180 & $10.21 \%$ \\
4 & Low self-confidence in writing & 179 & $10.15 \%$ \\
5 & Insufficient writing practice & 176 & $9.98 \%$ \\
6 & Fear of teacher's negative comments & 174 & $9.87 \%$ \\
7 & Pressure for perfect work & 174 & $9.87 \%$ \\
8 & Fear of writing tests & 171 & $9.70 \%$ \\
9 & High frequency of writing assignments & 168 & $9.53 \%$ \\
10 & Problems with topic choice & 151 & $8.56 \%$ \\
\hline
\end{tabular}


Table 3 showed that the most dominant cause of writing anxiety was linguistic difficulties which got total score of $205(11.63 \%)$. The second most dominant cause of writing anxiety was time pressure with total score of $185(10.49 \%)$. Then, the third and fourth most dominant cause of writing anxiety was insufficient writing technique $(10.21 \%)$ and low self-confidence in writing $(10.15 \%)$. Meanwhile, the lowest cause of writing anxiety was problems with topic choice which got total score of $151(8.56 \%)$. Causes of writing anxiety might differ from one situation to other situations. From the data, it can be concluded that linguistic difficulties became the main problem for students of English Language Education, Universitas Internasional Batam.

This study also interviewed students with low anxiety, moderate anxiety, and high anxiety. This study found that students with low, moderate, and high anxiety are found in each batch of English Language Education Study Program. To see the results clearly, the data is presented in Table 4 below.

Table 4. Distribution of writing anxiety in each batch of ELE

\begin{tabular}{lccc}
\hline & $\mathbf{2 0 1 7}$ & $\mathbf{2 0 1 8}$ & $\mathbf{2 0 1 9}$ \\
\hline Number of students & 13 & 14 & 22 \\
High anxiety & 9 & 11 & 15 \\
Moderate anxiety & 3 & 1 & 6 \\
Low anxiety & 1 & 2 & 1 \\
\hline
\end{tabular}

Table 4 showed that the writing anxiety (high, moderate, and low) was found in every batch of English Language Education student at Universitas Internasional Batam. Further, despite the higher batch of the students, students still experienced the writing anxiety. Besides, the distribution of the levels of writing anxiety was similar for each batch. Therefore, it can be concluded that writing anxiety did not depend on the higher levels or batch in the university. Or, in other words, the higher the batch did not determine the lower levels of the anxiety.

Besides, this study also disclosed that the distribution of writing anxiety was likely similar in each batch. However, a different case appeared in students of batch 2018 in which the ratio of moderate anxiety ( 1 student) was bigger than low anxiety ( 2 students) and the rest of the students were in the high level of writing anxiety. This study assumed this as a unique case that is essential to explore more deeply.

Therefore, this study interviewed each student from each batch who are categorized into low and high levels writing anxiety. This study also interviewed random students from each batch with moderate levels of writing anxiety.

\section{Case of students with low anxiety}

As presented in Table 4, low anxiety students were distributed in each batch of 2017, 2018, and 2019. Therefore, this study interviewed each student from batch of 2017, 2018, and 2019 that was indicated as students with low writing anxiety.

Student A admitted that he preferred writing in English to writing in Bahasa Indonesia. In other words, he did not avoid to write in English. He also viewed lecturer's comments as a booster for him to write better.

\section{"No, I do not feel that the comments from lecturer burden me. I see the comments as a challenge for me to be better".}

However, this study found that Student A found it overwhelmed when he was instructed to write an academic text or essay. He elaborated that he tended to overthink and felt under pressured when dealing with academic writing. He explained that writing academic essay required high level of technical writing, dictions/choice of words, and topic elaboration. Meanwhile, it was totally different when dealing with informal writing. Student A found that it was more comfortable when writing an informal text.

"I am not that confident to write any kind of texts, especially academic writing. I tend to overthink. I feel it is kind of hard when I am writing academic essay. It needs more high technical writing stuff. Then, I have 
to choose the best words, since it is an academic writing. So, I just feel under pressured."

As a summary, Student A reached low writing anxiety since he was not afraid of feeling by external factors, such as comments or judgment from lecturers or other friends. Also, he was confident enough to write in English with his English competences. However, as an EFL student, writing anxiety might appear when the demand of the writing levels was increasing.

The similar case also happened to Student B. Student B also preferred writing in English to writing in Bahasa Indonesia.

\section{"I prefer writing in English than Bahasa Indonesia. The rules (in English) are already clear."}

Student B did not view feedbacks from lecturers as a burden. However, she viewed comments or evaluation from lecturer or other classmates were motivating her to better her English writing.

"No. I am not afraid of teacher's feedback. Teacher's feedback motivates me for my English writing."

Similar to Student A, Student B found that it was still overwhelming to write an academic writing. Student $B$ reasoned that the most challenging aspect of academic writing was the familiarity of the topic. Therefore, it made her doubtful of the content and relevance of the writing.

\section{"... but, I still find (it is) difficult to write high-level of formality text, like an essay. The problem is related to the topic. Sometimes, I do not know about the topic. ... No, it does not mean I do not know what to write, miss. I am just doubtful whether my opinions are correct or not"}

Student A and Student B faced the similar writing anxiety when writing academic essay. The causes were slightly similar, namely topic, choice of words, and technical writing technique. In other words, low writing anxiety students still felt anxious in academic writing due to its high demands or requirements; not the teacher's demands or requirements. This study assumed that it is normal to happen since English is their foreign languages. In other words, EFL students might overthink to the limitation of rich vocabulary, writing technique, and topic knowledge.

This study found a different case from Student C. Unexpectedly, Student C stated that he preferred writing in Bahasa Indonesia to writing in English.

\section{"If I can choose, I prefer to write in Bahasa Indonesia. ... because Bahasa Indonesia is my first language. So, it is more comfortable for me (to write in Bahasa Indonesia)."}

The reason of Student $C$ reaching the low writing anxiety was due to his courage toward comments or feedbacks, his confidence in English writing, and his confidence of the results. He did not feel under pressured or stressed with his English writing exercises. Similar to Student A and B, he did not take into his heart when accepting feedbacks, but he interpreted the comments as an encouragement.

\section{"I do not feel anxious when writing in English. But, I still choose to write in Bahasa Indonesia. ... I am not afraid of evaluation from lecturers."}

Despite the low anxiety, Students $C$ still admitted that he still encountered some challenging aspects when writing in English. One of the aspects was the use of grammar. He emphasized that he was still confused on deciding the correct grammar to use when writing in English. He was also aware that it is since English was not his first language, so it was normal if he still produced some errors in writing. 


\begin{abstract}
"Yes, Miss. I still find the most difficult thing when writing is grammar. Sometimes, I do not know whether my grammar is already correct or not. Yeah, English is not my first language."
\end{abstract}

From the interviews with three students or participants, it can be summed up that the EFL students with low writing anxiety still felt anxious when writing in certain cases. Some still thought that their writing technique, knowledge, and vocabulary was not well-equipped to write higher demand of writing. Some still encountered linguistic problems to find the most appropriate linguistic features to use. It was clearly in accordance with the finding or causes of writing anxiety in which linguistic problems became the main obstacle of students of English Language Education, Universitas Internasional Batam.

\title{
Case of students with high anxiety
}

Table 4 clearly pictured that percentage of students with high writing anxiety took the biggest portion in each batch. Therefore, this study conducted an interview to dig deeper analysis of the cases of students with high anxiety. Apparently, this study found distinguished cases from each batch.

Student D already considered that writing was very overwhelming. She tended to compare her writing with her classmates' writing, especially in terms of vocabulary in which she judged that the use of vocabulary of her classmates' writing is even better than hers.

"I am not comfortable when writing in English, Miss. I know that my writing is not good. I always compare mine with others. My writing is not as good as theirs.

This comparison might appear since Student D sometimes took her classmates' writing as examples for her references. However, this might lead to either motivating or demotivating her. The demotivation might arise in writing tests since she assumed that her writing must be worse than others'.

"I know that my writing is not good, miss. Sometimes, I see my friend's writing to take example or search for good example. ... yes sometimes, miss. Sometimes, when doing exercises, I find it motivating me. But, when it comes to test, I always think that my writing is the worst."

Student D encountered some obstacles when writing in English. The biggest obstacle was to structure the words into good sentences. Student D tended to translate each word from Bahasa Indonesia to English and had problems with linguistic features of English. These problems led to the fear of incompetence to fulfill lecturer's demand or expectation.

"My biggest obstacle is how to structure the words and how to make sentences. I tend to translate from Bahasa Indonesia to English. Sometimes, I do not understand what to write. I know I cannot fulfill lecturer's expectation and I think I become traumatized when writing."

Other obstacles were topic knowledge and time constraint. Time constraint extremely affected the writing performance. Time constraint caused panic that led to the disappearance of writing ideas. Slightly similar, knowledge on topics also affected the writing performance.

"Deciding on topics depends on my knowledge, miss. ... Time constraints really affects me (when writing). I will be panic and my mind goes blank, especially in tests."

Despite those obstacles, the ultimate reason was due to lack of belief on performing good writing. Student D already considered that she could not produce good writing since she was not equipped with good writing ability. Apparently, the source of the self-doubt in terms of writing ability was due to her bad handwriting. Student D's hand writing was not readable; hence, she directly 
concluded that no one were able to read her writing. This led to her unconfidence to write, even when typing.

"I already know that my writing is not good. Even, people cannot read my handwriting. ...yes, although it is typing, I still feel my writing is not good, Miss."

This study found that it was an interesting as well as heartbreaking finding to disclose that a little judgment on a person's writing might cause a person's confidence and trust in writing competence. Hassan (2001) explained that students with good writing skill might perform worse since they did not believe their ability.

Another interesting case also appeared in Student E. Similar to Student D, Student E felt uncomfortable when writing in English. The feeling of uncomfortable was increasing since she found that their friend's comments or evaluations did not even encourage her to write better. Therefore, it led them to underestimate her competence on English writing.

"Yes, Miss. I don't feel comfortable to write in English. I sometimes ask my friends to look at my writing, but I don't think their comments motivate me."

The behavior of underestimating of her own competence led the feeling of afraid of lecturer's comments since she already judged her writing as poor. Besides, she was not confident with her vocabulary and grammar knowledge as well.

"I am afraid of comments from lecturer, Miss. Sometimes, I think my grammar and vocabulary is not good. I don't know many vocabularies, even when the test, I cannot open a dictionary. It makes me more afraid."

After a long interview, Student $\mathrm{E}$ admitted that she tended to translate when writing in English Furthermore, she translated each word from Bahasa Melayu to Bahasa Indonesia. After translating to Bahasa Indonesia, she translated the words into English. It took a quite long process for Student E to write in English. The long process of translating words when writing was getting more tense when she was dealing with time constraint that caused her more panic.

"Yes, Miss. I translate the words when writing. ... no, miss I think in Bahasa Melayu first. Then, I translate to Bahasa Indonesia and then, (I translate to) English. ... it gets harder when I have to write in a test because of the time limit."

This case of Student $\mathrm{E}$ was a case that could be dig deeper for richer analysis. It might happen to students whose first language is not Bahasa Indonesia. It might also be caused by the environment in which Bahasa Indonesia was not spoken daily or Bahasa Indonesia was only taught and used at schools.

Different from Student D \& E, Student F did not find any worriedness or fear on lecturer's comments or judgments. She valued that comments or evaluations either from lecturer or classmates were beneficial for her to advance her writing ability since she found that comments were encouraging.

"I am not afraid of comments from lecturer of friends. I feel that I need their comments so I can make writing better. ... I want to improve my writing, Miss."

In a conclusion, Student $\mathrm{F}$ had self-motivation to better her writing skills and did not avoid to write in English. She sometimes found time to write informal text, such as captions for Instagram. The obstacle of Student F came from her lack of competences in grammar. Student F sometimes felt 
hesitant to decide tenses to use and structure a sentence. In addition, another obstacle was tendency to translate Bahasa Indonesia to English when writing. In other words, linguistic difficulties caused writing anxiety of Student F.

\author{
"I sometimes write in English, miss, for example writing captions in \\ Instagram. ... in my opinion, my writing is not good because I still have \\ lack vocabulary. I don't know how to use tenses and structure sentences. \\ ... I tend to translate Bahasa Indonesia to English when writing."
}

This study found that the main cause of writing anxiety of Student $\mathrm{F}$ was linguistic problems. Student $\mathrm{F}$ found that she was not capable of having a good writing because she found that her English competence was poor, especially knowledge of vocabulary and grammar. This finding was also similar to the result of this study in which the most dominant cause of writing anxiety was linguistic difficulties.

In a nutshell, students with high writing anxiety might be triggered by several different reasons. Most of them admitted that linguistic difficulties were the main cause of writing anxiety. Some tended to translate from Indonesia, even from local language, when writing in English.

\title{
Discussion
}

This study found out that most EFL students at Universitas Internasional Batam have high writing anxiety. Boniface et al. (2008, cited in Miri \& Joia, 2018) explained that writing requires focus or attention, learning process, visual memory, and good performance. Further, Daud et al., (2007) mentioned that writing is quite tough and challenging for EFL students since English is not their first language and writing requires high technical requirements, such as grammar, diction or word choice, punctuation, and vocabulary.

This study also discovered that the most dominant type of writing anxiety of EFL students at Universitas Internasional Batam was cognitive anxiety. This result was consistent with the study of some researchers from Indonesia (See Masriani et al., 2018; Wahyuni \& Umam, 2017). In other words, it can be concluded that most of EFL students in Indonesia felt the writing anxiety because they overthought judgments from teachers and classmates. They sometimes underestimated their writing competences or they already thought that their writing was not good.

Therefore, this study also attempted to search for the cause of writing anxiety of EFL students at Universitas Internasional Batam. The results showed that there were three main causes of writing anxiety, namely linguistic difficulties, time pressure, and insufficient writing technique. The first dominant cause is linguistic difficulties, the second most dominant cause is time pressure, and the third most dominant cause is insufficient writing technique.

Linguistic difficulties became the main cause of writing anxiety of EFL students at Universitas Internasional Batam. Cheng (2004) mentioned that one of the causes of writing anxiety was linguistic difficulties. In other words, EFL students at Universitas Internasional Batam still had problems with the competences in grammar and vocabulary. It confirmed the results of interview that the students still tended to translate the words from Bahasa Indonesia to English when they were writing. Some students were still confused on how to structure the words and make sentences in English.

Even, the results of interview indicated that some students with low anxiety still think that their linguistic competences are not sufficient, specially dealing with grammar. Writing anxiety is common among advanced EFL learners (Marcos-Llinas \& Garau, 2009, cited in Miri \& Joia, 2018). In addition, students think that formal writing limits their writing freedom and creativity (Lin, 2009, cited in Miri \& Joia, 2018). However, the essential point lied on the way the students with low anxiety attempted to handle their anxiety more positively, such as overcoming the fear of comments or fear of making errors and not avoiding to write in English. In addition, Zhang (2011) claimed that language of difficulties might affect the students to become lazier to write. Hence, this study may suggest to the lecturers and students to provide more time to sharpen the knowledge of English grammar and vocabularies at Universitas Internasional Batam to help the students to have a better writing.

The second most dominant cause was time pressure. This cause might relate to the language difficulties that were faced by the students. The students were not equipped with good linguistic knowledge that affected their confidence when writing with time constraints. Rezaei and Jafari (2014) assumed that time constraint caused students to feel more pressured since writing is a productive skill. 
Some students admitted that they could not find any idea to write when writing with time limit since they were also expected to fulfill the expectation from the lecturers.

The third most dominant cause was insufficient writing technique. Hassan (2001) mentioned that writing demands many requirements, such as grammar, mechanics, word choice, coherence, idea organization, and etc. These demands affected the EFL students who did not have good writing competence to feel anxious when writing in English. This statement was in line with the result of interview. Students with high writing anxiety found that they were not equipped with good writing technique, such as making words into good sentences, structuring ideas, selecting the tenses (grammar), and etc. In addition, students with low anxiety also felt the same experience. They found that their writing technique was not sufficient when they were expected to write higher demand of writing that requires them to have higher writing techniques. Therefore, the lecturers of English Language Education, Universitas Internasional Batam, need to give more practices and feedbacks to the students to sharpen and improve their writing techniques. They can implement ungraded writing activities. Sharp (1997, cited in Syarifudin, 2020) proposed ungraded writing activities to help the students to manage their anxiety when they have to write in English. The examples of upgrading writing activity are journal writing, free writing, and paper revision.

In a nutshell, it is common for EFL students to have high writing anxiety. The writing anxiety were caused by several aspects, such as linguistic problems, time pressure, and insufficient writing technique. Students with both high and low writing anxiety admitted that they still experienced linguistic problems and insufficient writing techniques when it comes to writing with higher demand. Therefore, similar to other previous studies, linguistic problems still became the main cause of writing anxiety.

\section{CONCLUSION}

Writing in English may be overwhelming for EFL College Students since English is not their first language. Therefore, it is normal that the EFL College Students feel anxious when writing in English. Students may have different levels of anxiety depending on some certain causes. This study found that the most dominant level of writing anxiety in English Language Education (ELE) students at Universitas Internasional Batam is high-level writing anxiety (71.43\%). Meanwhile, the students with moderate anxiety reach $20.41 \%$ and low anxiety is $8.16 \%$. The distribution of the proportion of the levels is similar to each grade. In other words, students with the low anxiety reaches the lowest percentage and high anxiety reaches the highest percentage in each batch. In conclusion, the higher the grade does not affect students to have lower writing anxiety.

In terms of types of writing anxiety, this study found that the cognitive anxiety was the most dominant type of writing anxiety with the means of 26.37. On the other hand, somatic anxiety reached the mean of 26.08 and avoidance behavior reached the mean of 18.98 . When studying the cause of writing anxiety, this study found that the most dominant causes of writing anxiety was linguistic difficulties, time pressure, and insufficient writing technique. Students with low writing anxiety still felt anxious when they were writing high-formality text that needs high demand and felt unconfident with their linguistic competence. On the other hand, students with high writing anxiety may have various causes. Some students had a low confidence when writing. Some students were not equipped with good linguistic competence, especially knowledge in grammar and vocabulary. Some students might have special case in which they need to translate words by words from their local language to English. Therefore, by knowing deeply the cause of writing anxiety experienced by the students, it is expected that the results can contribute as a foundation for the development of appropriate teaching methods/strategies/techniques to provide solutions to minimize students' writing anxiety. Besides, this study may contribute to the development or improvement of curriculum structure of English Language Education to prepare their students to equip the students with sufficient linguistic competences that may help them to have better writing techniques.

\section{ACKNOWLEDGEMENT}

The author would like to appreciate Universitas Internasional Batam for giving the opportunity to the author to conduct this research. This research is a part of Internal Research Grant provided by Universitas Internasional Batam for the lecturers. Therefore, the fund for this research and its publication is from Universitas Internasional Batam. The author also would like to thank English Language Education, Universitas Internasional Batam, especially the students who became the subject of this research to spare their time to fill in the questionnaire and be interviewed. 


\section{REFERENCES}

Al-Sawalha, A. M. S., \& Chow, T. V. F. (2012). The effects of writing apprehension in English on the writing process of Jordanian EFL students at Yarmouk University. International Interdiciplinary Journal of Education, 1(1), 6-14.

Ary, D., Jacobs, L., Razavieh, A., \& Sorensen, C. K. (2010). Introduction to Research in Education (10th ed.). Nelson Education, Ltd.

Bloom, L. Z. (1981). Why Graduate Students Can't Write: Implications of Research on Writing Anxiety for Graduate Education. Journal of Advanced Compositions, 2(2).

Chamot, A. U. (2005). Language learning strategy instruction: Current issues and research. Annual Review of Applied Linguistics, 25, 112-130. https://doi.org/10.1017/S0267190505000061

Cheng, Y. S. (2004). A measure of second language writing anxiety: Scale development and preliminary validation. Journal of Second Language Writing, 13(4), 313-335. https://doi.org/10.1016/j.jslw.2004.07.001

Creswell, J. W. (2012). Educational research: Planning, conducting, and evaluating quantitative and qualitative research (4th ed.). Pearson Education, Inc.

Daud, N. S. M., Daud, N. M., \& Kassim, N. L. A. (2007). Second language writing: Cause or effect? Malaysian Journal of ELT Research Inaugural, 1(9).

Fitrinada, D. M., Loeneto, B. A., \& Fiftinova. (2018). Students' writing anxiety and its correlation with writing performance. The Journal of English Literacy Education, 5(2), 194-207.

Hassan, B. A. (2001). The relationship of writing apprehension and self-esteem to the writing quality and quantity of EFL university students. Eric, 4.

Horwitz, E. K. (2001). Language anxiety and achievement. Annual Review of Applied Linguistics, 21, $112-126$.

Horwitz, E. K., Horwitz, M. B., \& Cope, J. (1986). Foreign language classroom anxiety. The Modern Language Journal, 70(2), 125-132. https://doi.org/10.1111/j.1540-4781.1986.tb05256.x

Kusumaningputri, R., Ningsih, T. A., \& Wisasongko. (2018). Second language writing anxiety of Indonesian EFL students. Lingua Cultura, 12(4), 357-362. https://doi.org/10.21512/lc.v12i4.4268

MacIntyre, P. D., \& Gardner, R. C. (1994). The subtle effects of language anxiety on cognitive processing in the second language. Language Learning, 44(2), $283-305$. https://doi.org/10.1111/j.1467-1770.1994.tb01103.x

Masriani, E., Mukhaiyar, \& Wahyuni, D. (2018). Writing anxiety and writing strategies used by English department students of Universitas Negeri Padang. Lingua Didaktika, 12(1), $76-85$. https://doi.org/10. 24036/1d. v12i1.8766

Miri, M. A., \& Joia, J. (2018). Writing Anxiety in an Afghan EFL Setting: Voices From Five Afghan Students. Journal of Foreign Languange Teaching and Learning, 3(1). https://doi.org/10.18196/ftl.3125

Rezaei, M., \& Jafari, M. (2014). Investigating the levels, types, and causes of writing anxiety among Iranian EFL students: A mixed method design. Procedia - Social and Behavioral Sciences, 98, 15451554. https://doi.org/10.1016/j.sbspro.2014.03.577

Syarifudin, S. (2020). Survey on EFL Students' Writing Anxiety: Level, Types, and Causes. Eralingua: Jurnal Pendidikan Bahasa Asing Dan Sastra, 4(2), 122. https://doi.org/10.26858/eralingua.v4i2.13925

Takahashi, A. (2009). Self-perception of English ability: Is it related to proficiency and/or class performance? Niigata Studies in Foreign Languages and Cultures, 14, 39-48. http://dspace.lib.niigata-u.ac.jp:8080/dspace/handle/10191/9349

Wahyuni, S., \& Umam, M. K. (2017). An analysis on writing anxiety of Indonesian college learners. Journal of English Education and Linguistic Studies, 4(1), 105-128.

Zhang, H. (2011). A study on ESL writing anxiety among Chinese English majors: Causes, effects and coping strategies for ESL writing anxiety. Kristiandstad University Sweden. 